\title{
Growth of the corpus luteum and its progesterone content during pregnancy in the tammar wallaby, Macropus eugenii
}

\author{
Marilyn B. Renfree, S. W. Green and I. R. Young* \\ School of Environmental and Life Sciences, Murdoch University, Western Australia 6153
}

\begin{abstract}
Summary. Corpora lutea were obtained from wallabies at different stages of pregnancy, following removal of pouch young to initiate embryonic development. Progesterone was present at a concentration of $11.3 \mathrm{ng} / \mathrm{mg}$ in quiescent corpora lutea from lactating animals. Progesterone values rose with increasing corpus luteum weight to reach a maximum of $40-50 \mathrm{ng} / \mathrm{mg}$ in corpora lutea weighing $50-60 \mathrm{mg}$. Total progesterone reached a maximum of $1500 \pm 300$ (s.e.m.) ng at Days 21-23 after removal of pouch young, but fell markedly at Days 24 and 25 (900 $\pm 150 \mathrm{ng}$ ) immediately before parturition.
\end{abstract}

\section{Introduction}

In the marsupials, the life of the corpus luteum is not prolonged by the presence of a conceptus, although in the Peramelidae (bandicoots) the corpus luteum persists during lactation (Hughes, 1962; Tyndale-Biscoe, 1973; Gemmell, 1977). There is apparently no luteolysin elaborated by the uterus, since hysterectomy has no effect on the corpus luteum of the opossum Didelphis or the brush possum Trichosurus (Hartman, 1925; Clark \& Sharman, 1965). During lactation the corpus luteum is either quiescent or absent in most marsupials. In the macropodid marsupial, the tammar wallaby, Macropus eugenii, the corpus luteum formed after a post-partum oestrus and mating is held quiescent during lactation by the secretion of prolactin from the pituitary (Tyndale-Biscoe \& Hawkins, 1977). During pregnancy in this species the corpus luteum reaches a maximum size in mid-gestation, but declines towards the end of pregnancy (Renfree \& Tyndale-Biscoe, 1973). In the red kangaroo, progesterone has been extracted from a corpus luteum of quiescence and a corpus luteum associated with a luteal uterus (Lindner \& Sharman, 1966). In the tammar, progesterone levels in the peripheral plasma show a small increase in pregnant and cyclic animals around Days $8-10$, but there is also apparently a second rise towards the end of pregnancy before parturition (Lemon, 1972). The present study was conducted to determine the amount of progesterone in the corpus luteum throughout pregnancy.

\section{Materials and Methods}

\section{Collection and treatment of samples}

Corpora lutea were collected at surgery from tammar wallabies used in a study of the effects of corpus luteum removal during pregnancy, as described previously (Young \& Renfree, 1979). The corpora lutea $(\mathrm{CL})$ were weighed wet and stored at $-15^{\circ} \mathrm{C}$ until used for analysis. The CL were homogenized in $100 \mu$ l glass-distilled water. The homogenate was placed into extraction

* Present address: Department of Physiology, University of Queensland, St Lucia, Queensland 4067, Australia. 
tubes and the volume was made up to $1 \mathrm{ml}$. Samples were extracted in $5 \mathrm{ml}$ petroleum spirit (b.p. $40-60^{\circ} \mathrm{C}$ : British Drug Houses Chemicals, Port Fairy, Victoria, Australia) by vigorous shaking at $4^{\circ} \mathrm{C}$ for $20 \mathrm{~min}$. The solvent phase was separated from the aqueous phase by freezing, and decanted into clean tubes containing $1 \mathrm{ml}$ distilled water. The tubes were re-shaken for $10 \mathrm{~min}$, frozen and the solvent phase decanted into clean tubes. The extract was dried at $45^{\circ} \mathrm{C}$ under dry nitrogen, dissolved in $1 \mathrm{ml}$ redistilled absolute ethanol and stored at $-20^{\circ} \mathrm{C}$. Aliquots were used for assay. All tubes and other glassware were rinsed with redistilled acetone before use.

\section{Chemicals and apparatus}

Phosphate-saline buffers were prepared from Analar/Univar chemicals obtained from British Drug Houses and Ajax-Chemicals, Sydney, Australia. Sodium azide and gelatine were laboratory reagent grade from Ajax-Chemicals.

The charcoal suspension was prepared from Norit A (Decolorizing Carbon: Pfanstiehl Laboratories, Waukegan, Illinois) and dextran T70 (Pharmacia Ltd, Uppsala, Sweden).

Progesterone was obtained from Steraloids, Inc, Wilton, New Hampshire, U.S.A., and $\left[1,2,6,7(\mathrm{n})-{ }^{3} \mathrm{H}\right]$ progesterone (sp. act. $85 \mathrm{Ci} / \mathrm{mmol}$ ) from The Radiochemical Centre, Amersham, Bucks, U.K. Scintillation fluid was prepared from Triton X-100 (Sigma Chemical Co., St Louis, Missouri, U.S.A.) and 2,5-diphenyloxazole (P.P.O.: Searle Nucleonics, Sydney, Australia). Toluene was industrial grade supplied by Shell Chemicals (Perth, Australia).

Pipetting was carried out using Eppendorf pipettes (Hamburg, Germany) or Finnpipettes (Helsinki, Finland). Radioimmunoassays were performed in $12 \times 100 \mathrm{~mm}$ Pyrex test tubes (Corning, Sydney, Australia). Radioactivity was determined using a Packard Tri-Carb Liquid Scintillation Spectrometer, Model 3255.

\section{Antiserum and specificity}

The antiserum was provided by Dr R. I. Cox, Hormone Assay Group, CSIRO Division of Animal Production, Sydney, and was raised in sheep to progesterone-11-hemisuccinate-BSA (Steraloids). Antibody dilution curves were prepared to obtain the dilution for $50 \%$ binding which was 1:9000. The specificity of the antiserum from Sheep 334 was characterized previously by the CSIRO Hormone Assay Group and they provide the following percentage cross-reactions: progesterone, $100 ; 11 \beta$-hydroxyprogesterone, $27 ; 17 \alpha$-hydroxyprogesterone, $0.3 ; 20 \alpha$-hydroxy-4-pregnene-3-one, $0.6 ; 20 \beta$-hydroxy-4-pregnene-3-one, 0.3 ; pregnenelone, $0.6 ; 3 \beta, 17$-dehydroxy-5-pregnene-20-one, $<0.02 ; 5 \beta$-pregnane-3 $\alpha, 20 \beta$-diol, $0.03 ; 5 \beta$-pregnane$3 \alpha$-2 $\alpha$-diol, 0.03 ; $5 \beta$-pregnane-3,20-dione, 1.4 ; cortisol, 0.01 ; corticosterone, 5.8 ; 11 -deoxycorticosterone, 6.9. In addition, we tested 5 $\alpha$-pregnanedione, 11- $\beta$-hydroxyprogesterone, desoxycorticosterone and corticosterone and calculated \% cross-reaction as (ng progesterone required to depress c.p.m. by $50 \% / \mathrm{ng}$ steroid required to depress c.p.m. by $50 \%$ ) $\times 100$. We obtained the following cross-reactions: $5 \alpha$-pregnanedione, $4.3 \% ; 11 \beta$-hydroxyprogesterone, $17.7 \%$; desoxycorticosterone, $2.0 \%$; and corticosterone, $2.6 \%$.

\section{Progesterone assay and assay validation}

The progesterone concentration in the $\mathrm{CL}$ was determined by diluting the homogenate extract $1: 30$ in redistilled ethanol and pipetting $25 \mu \mathrm{l}(1: 1200), 50 \mu \mathrm{l}(1: 600)$ and $100 \mu \mathrm{l}$ $(1: 300)$ aliquots into $12 \times 100 \mathrm{~mm}$ Pyrex tubes. At the same time a series of standard progesterone concentrations was prepared containing $0,50,100,200,400$ and $800 \mathrm{pg}$ in 25,50 or $100 \mu \mathrm{l}$ redistilled ethanol, depending on the dilution of the CL extract. All tubes containing standards or samples were then dried under nitrogen at $45^{\circ} \mathrm{C}$. Antiserum 334 was then added to all tubes in $600 \mu \mathrm{l}$ phosphate buffer, $\mathrm{pH} 7.1\left(15.04 \mathrm{~g} \mathrm{Na} \mathrm{HPO}_{4} \cdot 12 \mathrm{H}_{2} \mathrm{O}, 2.5 \mathrm{~g}\right.$ 
$\mathrm{NaH}_{2} \mathrm{PO}_{4} \cdot 2 \mathrm{H}_{2} \mathrm{O}, 9.0 \mathrm{~g} \mathrm{NaCl}, 1.0 \mathrm{~g} \mathrm{NaN}_{3}, 1.0 \mathrm{~g}$ gelatin in 1 litre glass-distilled water) at $1: 9000$ dilution which bound $45-60 \%$ of 25000 d.p.m. The samples were mixed and allowed to stand at room temperature for $30 \mathrm{~min}$. This was followed by the addition of $100 \mu \mathrm{l}\left[{ }^{3} \mathrm{H}\right]$ progesterone, (approx. 25000 d.p.m.), mixing and incubation at $4^{\circ} \mathrm{C}$ for $18 \mathrm{~h}$. After incubation, $200 \mu \mathrm{l}$ of a charcoal suspension containing $250 \mathrm{mg}$ charcoal and $25 \mathrm{mg}$ dextran T70 per $100 \mathrm{ml}$ phosphate buffer were added at $4^{\circ} \mathrm{C}$. The samples were mixed and allowed to stand at $4^{\circ} \mathrm{C}$ for $10 \mathrm{~min}$, then centrifuged at $1550 \mathrm{~g}$ for $10 \mathrm{~min}$. The supernatant was decanted into scintillation vials and counted in $5 \mathrm{ml}$ toluene-Triton X-100 (2:1 w/v) scintillation fluid (0.5\% PPO) after allowing a minimum of $10 \mathrm{~h}$ for equilibration.

Parallelism between the standard curve and sample was determined by diluting known amounts of the CL extract, and comparing with the standard curve, using 6 aliquots at each point in both cases. The regression equations were $y=-0.205 x+4.000$ for the standard curve and $y=-206 x+4.004$ for the CL extract. The recovery of ${ }^{3} \mathrm{H}$-labelled progesterone added to homogenized corpora lutea was $95 \%$, and values were corrected accordingly.

Sensitivity. The sensitivity of the standard curve was taken to be the smallest amount of steroid that was significantly different from zero at the $95 \%$ confidence limit. For the standard curve, derived by adding known amounts of progesterone to water, the sensitivity was $30 \mathrm{pg}$ (at $95 \%$ confidence limits), and for two ethanol standard curves used for the assay of CL extracts it was 20 and $25 \mathrm{pg}$. These values served as the sensitivity of the assay of CL extract because the samples were ethanol extracts and not biological fluids.

Accuracy. The accuracy of the assay was tested by adding known quantities of steroid to samples of CL extract and measuring the amounts of steroid present. The correlation between the amounts added $(0,50,100,200,400$ and $800 \mathrm{pg})$ and amounts measured $(65,65,90,400$, 525 and $950 \mathrm{pg}$ respectively) was taken as a measure of accuracy. The relationship between a standard curve in which known amounts of steroid were added to water $(y=-0 \cdot 210 x+4 \cdot 167)$ and another curve derived by adding the same quantities of steroid to the CL extract $(y=$ $-2 \cdot 11 x+4 \cdot 143)$ was examined. The curves were parallel and the correlation coefficient was 0.998 (Snedecor \& Cochran, 1967). The mean \pm s.e.m. coefficient of variation of 6 calibration lines containing water was $5.45 \pm 0.73 \%$ and of 6 calibration lines containing CL extract was $4 \cdot 81 \pm 1 \cdot 73 \%$.

Precision. Precision of the assay was estimated by measures of the variability of replicate measurements of the same sample within an assay and between assays. The most frequently cited parameters are standard deviation and coefficient of variation. In the assay of CL extracts all samples within an assay were measured in triplicate and these estimates permitted an evaluation of within-assay variation.

All measurements of the CL extracts were grouped according to magnitude (Table 1). The mean and variance of each triplicate set was calculated and a mean and s.d. was derived for all values within each range. These are the values listed in Table 1, and gave a coefficient of variation of $18 \%$ within assays. The standard deviations compare favourably with those of Heap, Holdsworth, Gadsby, Laing \& Walters (1976) although the coefficients of variation are greater than those sited by Abraham, Swerdloff, Tulchinsky \& Odell (1971).

Table 1. Intra-assay variation in triplicate analyses of progesterone in corpus luteum extracts

\begin{tabular}{ccccc}
\hline $\begin{array}{c}\text { Range of progesterone } \\
\text { conc. (ng/mg) }\end{array}$ & $\begin{array}{c}\text { No. of } \\
\text { triplicate } \\
\text { samples }\end{array}$ & $\begin{array}{c}\text { Mean conc. } \\
\text { (ng/mg) }\end{array}$ & $\begin{array}{c}\text { Standard } \\
\text { deviation }\end{array}$ & $\begin{array}{c}\text { Coefficient of } \\
\text { variation (\%) }\end{array}$ \\
\hline $0-9.9$ & 34 & $6 \cdot 4$ & $1 \cdot 3$ & 20 \\
$10-19.9$ & 43 & $13 \cdot 6$ & $2 \cdot 4$ & 17.6 \\
$20-29.9$ & 30 & $24 \cdot 1$ & $4 \cdot 4$ & 18.2 \\
$30-42$ & 13 & 34.3 & 6.6 & 19.2 \\
\hline
\end{tabular}


To estimate between-assay variation, 21 samples were measured in two separate assays in triplicate. The difference between the pairs of triplicate measurements was $d$ and the standard deviation, calculated by $\sqrt{\sum d^{2} / 2 n}$ where $n$ is the number of duplicate estimates, was found to be 3.9. The coefficient of variation was calculated from $S /\left(\sum d / n\right)$ and was $6.09 \%$. This value compared well with the published values of 18-20\% (Abraham et al., 1971).

\section{Results}

\section{Corpus luteum weights}

The wet weights of CL are given in Text-fig. 1. The weights increased from a value of about $8 \mathrm{mg}$ to reach a peak of $50-60 \mathrm{mg}$ at Day 15 . Weights remained high until immediately before parturition when values dropped to a mean of $28 \mathrm{mg}$. No weights were obtained from CL after birth. There was wide variation in CL weights at Days 10 and 15, before attachment of the embryonic vesicle at Day 17-19. At these times embryonic size was also highly variable,

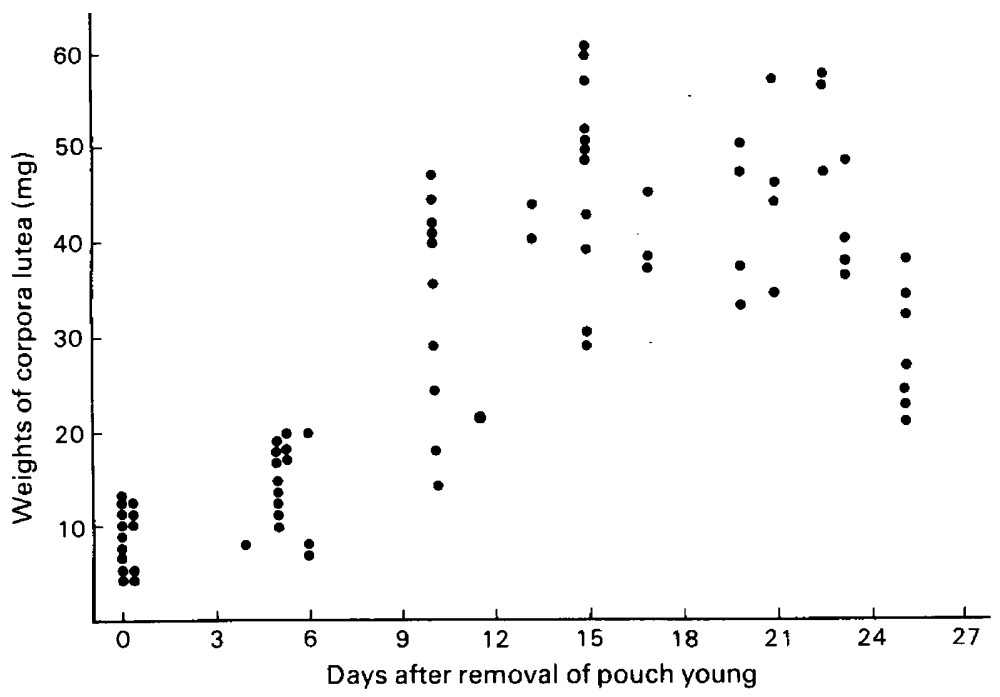

Text-fig. 1. Scattergram of the weight, throughout gestation, of corpora lutea collected from 77 animals. The variation in weight at each day of gestation related to the size of the embryo (Textfig. 2).

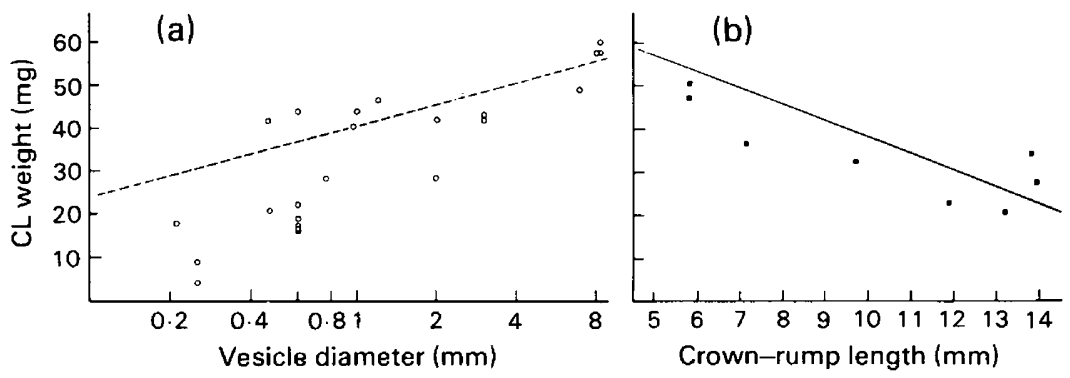

Text-fig. 2. Relationship between corpus luteum weight and (a) vesicle diameter and (b) crownrump length of the embryo. The regression equations are (a) $y=3.820 x+24.487, r=0.717$ and (b) $y=-2.478 x+59.284, r=-0.827$. The change to the inverse relationship occurs at attachment of the placenta to the endometrium. 
suggesting variation in the time of resumption of development after removal of the pouch young (RPY). When this was taken into consideration, a direct relationship appears between embryo size and CL weight before attachment (Text-fig. 2a) and an inverse relationship after attachment (Text-fig. 2b).

\section{Progesterone concentrations in corpora lutea}

Progesterone concentration increased steadily to reach the highest values of $32.0 \pm 19.4$ $\mathrm{ng} / \mathrm{mg}$ at Day 23 after RPY (Table 2). At Days 24 and 25, values decreased only slightly on a per mg basis, despite the fall in CL weight (Text-fig. 1) at this time. However, total progesterone/ corpus luteum showed a steady rise, first noticeable between Days 10 and 13 after RPY, the highest concentration occurring between Days 21 and 23 (Table 2). At Day 25 there was a marked drop in total progesterone concentration in the CL.

Table 2. Mean \pm s.e.m. concentration and total content of progesterone in corpora lutea of tammar wallabies at different stages of gestation

\begin{tabular}{cccc}
\hline $\begin{array}{c}\text { Day of } \\
\text { gestation }\end{array}$ & $\begin{array}{c}\text { No. of } \\
\text { samples }\end{array}$ & $\begin{array}{c}\text { Concentration } \\
(\mathrm{ng} / \mathrm{mg})\end{array}$ & $\begin{array}{c}\text { Total content } \\
\text { (ng) }\end{array}$ \\
\hline $0^{*}$ & 7 & $11 \cdot 28 \pm 2 \cdot 73$ & $101 \cdot 0 \pm 33 \cdot 0$ \\
5 & 6 & $10 \cdot 04 \pm 0 \cdot 5$ & $139 \cdot 5 \pm 7 \cdot 3$ \\
10 & 13 & $11 \cdot 9 \pm 0 \cdot 51$ & $349 \cdot 7 \pm 17 \cdot 4$ \\
13 & 2 & $14 \cdot 7 \pm 3 \cdot 15$ & $609 \cdot 7 \pm 106 \cdot 7$ \\
15 & 13 & $17 \cdot 8 \pm 2 \cdot 16$ & $672 \cdot 8 \pm 32 \cdot 5$ \\
17 & 3 & $24 \cdot 4 \pm 7 \cdot 49$ & $941 \cdot 5 \pm 177 \cdot 3$ \\
20 & 4 & $18 \cdot 0 \pm 2 \cdot 60$ & $733 \cdot 2 \pm 31 \cdot 8$ \\
21 & 4 & $23 \cdot 0 \pm 3 \cdot 7$ & $1230 \cdot 0 \pm 178 \cdot 5$ \\
22 & 3 & $32 \cdot 0 \pm 19 \cdot 4$ & $1178 \cdot 0 \pm 75 \cdot 2$ \\
23 & 5 & $28 \cdot 6 \pm 3 \cdot 43$ & $1124 \cdot 8 \pm 122 \cdot 5$ \\
25 & 6 & $22 \cdot 2 \pm 4 \cdot 16$ & $623 \cdot 2 \pm 139 \cdot 3$ \\
\hline
\end{tabular}

* Lactational quiescence.

\section{Discussion}

The corpus luteum of the tammar wallaby contains appreciable quantities of progesterone throughout gestation. The total amount present in each corpus luteum correlates well with size of the gland, but by Day 24 both the size and progesterone content drop markedly. The weight measures also correlate well with size measurements reported previously (Renfree \& TyndaleBiscoe, 1973).

The concentration of progesterone in the peripheral plasma of the tammar is remarkably low when measured by competitive protein binding (Lemon, 1972) or by radioimmunoassay (Renfree \& Heap, 1977), but the highest value occurs towards the end of pregnancy (around Day 23). This peak in peripheral plasma progesterone was abolished in 3 animals that were ovariectomized at Day 10 after RPY, suggesting that all measurable progesterone is derived from the ovary (Lemon, 1972). The progesterone content of the CL reaches peak concentration at about the same time as that found in the plasma, lending further support to the idea that plasma progesterone is derived predominantly at this time from the CL.

Total progesterone content per CL has a slight biphasic pattern, with a smaller, earlier rise occurring between Days 13 and 17. Lemon (1972) showed a similar pattern in plasma from 13 pregnant animals but the first 'peak' occurred somewhat earlier at Day 10. It is possible that the biphasic nature of the progesterone concentration is an artefact due to sample size, but the drop in concentration is consistent in all Day 20 samples in the present study.

In the tammar wallaby the CL is necessary for at least the first 17 days of pregnancy for successful parturition and the initiation of lactation (Young \& Renfree, 1979). The increase in 
progesterone concentration in the $C L$ and in the plasma up to and after this time is compatible with the proposed role of progesterone in relaxation of the urogenital canal (Tyndale-Biscoe, 1966) and in the initiation of lactation (Young \& Renfree, 1979). However, since the myometrium remains quiescent under the influence of progesterone during pregnancy (Young, 1977), it is not surprising to find a fall in CL progesterone content by Day 25 after RPY, only 12 days before parturition.

We thank Dr R. B. Heap for numerous suggestions and guidance on the assay techniques and helpful criticism of the manuscript; Dr R. McKay for help with the statistics; Alison Dunning for assistance; and Dr R. I. Cox, Hormone Assay Group, CSIRO, Box 239, Sydney 2148, for the gift of the antisera. This study was supported by grants from the National Institutes of Health (HD-09387) and the Australian Research Grants Committee (DI-15759).

\section{References}

Abraham, G.E., Swerdloff, R., Tulchinsky, R. \& Odell, W.D. (1971) Radioimmunoassay of plasma progesterone. J. clin. Endocr. Metab. 32, 619-624.

Clark, M.J. \& Sharman, G.B. (1965) Failure of hysterectomy to affect the ovarian cycle of the marsupial, Trichosurus vulpecula. J. Reprod. Fert. 10, 459-461.

Gemmell, R.T. (1977) The structure and function of the corpus luteum of lactation of the bandicoot, Isoodon macrourus. Theriogenology 8, 143, Abstr.

Hartman, C.G. (1925) Hysterectomy and the oestrous cycle in the opossum. Am. J. Anat. 35, 25-29.

Heap, R.B., Holdsworth, R.J., Gadsby, J.E., Laing, J.A. \& Waiters, D.E. (1976) Pregnancy diagnosis in the cow from milk progesterone concentration. Br. vet.J. 132, 445-464.

Hughes, R.L. (1962) Role of the corpus luteum in marsupial reproduction. Nature, Lond. 194, 890891.

Lemon, M. (1972) Peripheral plasma progesterone during pregnancy and the oestrous cycle in the tammar wallaby, Macropus eugenii. J. Endocr. 55, 63-71.

Lindner, H.R. \& Sharman, G.B. (1966) The pregnancy hormone in the red kangaroo (Megaleia rufa Desm). Abstr. No. 742 in Hormonal Steroids (Abstracts of Second Int. Congr.) (International Congr. Series no. 111), p. 371. Excerpta Medica, Amsterdam.
Renfree, M.B. \& Heap, R.B. (1977) Steroid metabolism in the placenta, corpus luteum and endometrium of the marsupial, Macropus eugenii. Theriogenology 8 , 164, Abstr.

Renfree, M.B. \& Tyndale-Biscoe, C.H. (1973) Intrauterine development after diapause in the marsupial Macropus eugenii. Devl Biol. 32, 28-40.

Snedecor, G.W. \& Cochran, W.G. (1967) Statistical Methods. Iowa State University Press.

Tyndale-Biscoe, C.H. (1966) The marsupial birth canal. Symp. Zool. Soc. Lond. 15, 233-250.

Tyndale-Biscoe, C.H. (1973) Life of Marsupials. Edward Arnold Publ. London.

Tyndale-Biscoe, C.H. Hawkins, J. (2977) The corpora lutea of marsupials. Aspects of function and control. In Reproduction and Evolution, pp. 245-252. Eds J. H. Calaby \& C. H. Tyndale-Biscoe. Australian Academy of Science, Canberra.

Young, I.R. (1977) Relationship of hormonal and reproductive status to myometrial activity in the tammar wallaby. Theriogenology 8, 207, Abstr.

Young, I.R. \& Renfree, M.B. (1979) The effects of corpus luteum removal during gestation on parturition in the tammar wallaby, Macropus eugenii. J. Reprod. Fert. 56, 249-254. 